\title{
Use of Conventional Ultrafiltration in Patients with Pulmonary Hypertensive Mitral Valve Disease Undergoing Valve Surgery
}

\author{
Burak Can Depboylu ${ }^{1,}$, Serkan Yazman ${ }^{2}$, Bugra Harmandar ${ }^{1}$ \\ ${ }^{1}$ Department of Cardiovascular Surgery, Faculty of Medicine, Mugla Sitki Kocman University, Mugla, Turkey \\ ${ }^{2}$ Cardiovascular Surgery Clinic, Mugla Sitki Kocman University, Training and Research Hospital, Mugla, Turkey
}

Email address:

burakdepboylu@mu.edu.tr (B. C. Depboylu)

${ }^{*}$ Corresponding author

\section{To cite this article:}

Burak Can Depboylu, SerkanYazman, Bugra Harmandar. Use of Conventional Ultrafiltration in Patients with Pulmonary Hypertensive Mitral Valve Disease Undergoing Valve Surgery. Cardiology and Cardiovascular Research. Vol. 2, No. 2, 2018, pp. 23-28.

doi: $10.11648 /$ j.ccr.20180202.12

Received: April 24, 2018; Accepted: May 14, 2018; Published: June 12, 2018

\begin{abstract}
Adverse effects of cardiopulmonary bypass on blood and lungs are encountered more severelyin pulmonary hypertensive patients undergoing mitral valve surgery. Aim of this study is to identify the favorable effects of conventional ultrafiltration on postoperative pulmonary functions, hemodynamics, morbidity or mortality in pulmonary hypertensive patients undergoing mitral valve surgery. 40 patients with severe pulmonary hypertension who underwent mitral valve surgery were included in study. Patients were divided into two groups according to whether conventional ultrafiltration was applied or not. Demographic data, preoperative transthoracic echocardiography, respiratory functions, complete blood count, biochemical parameters, alterations in pulmonary functions, bleeding, use of inotropic agents and blood products, intubation time, mortality, morbidity, length of intensive care unit and hospital stay, were evaluated. Intubation time (7.97 $\pm 2.77 \mathrm{vs.} \mathrm{10.12 \pm 2.95;}<0.05)$, intensive care stay $(42.20 \pm 65.99$ vs. $44.25 \pm 14.13 ; \mathrm{p}<0.05)$, hospital stay $(7.20 \pm 1.13$ vs. $10.12 \pm 3.27 ; \mathrm{p}<0.05)$, bleeding $(370.00 \pm 216.28$ vs. $506.25 \pm 247.03 ; \mathrm{p}<0.05)$ were significantly shorter in study group. Use of blood products $(4.20 \pm 1.23$ vs. $4.90 \pm 2.13 ; \mathrm{p}>0.05)$ and inotropic agents $(14$ vs. $18 ; \mathrm{p}>0.05)$ were less than the control group. Increase of pulmonary compliance, cardiac index, oxygen index, decrease of alveolar-arterial oxygen pressure difference and ventilation index were significant in both groups. Hematocrit $(28.07 \pm 3.18$ vs. $26.96 \pm 2.51 ; p>0.05)$ and white blood cell (13.56 \pm 2.37 vs. $13.03 \pm 2.51$; $\mathrm{p}>0.05)$ were higher in the study. No morbidity and mortality were presentin both groups. Conventional ultrafiltration decreased the intubation time, intensive care unit stay, hospital stay, bleeding, use of blood products and inotropic agents. Favorable effects were also detected on pulmonary compliance, cardiac index, oxygen index, alveolar-arterial oxygen pressure difference and ventilation index. Studies with larger patient population, application of conventional and modified ultrafiltration together may give significant results for pulmonary functions.
\end{abstract}

Keywords: Cardiopulmonary Bypass, Cardiac Surgery, Mitral Valve Disease, Ultrafiltration, Morbidity

\section{Introduction}

The group of mitral valve diseases is one of the major reasons of secondary pulmonary hypertension. In the beginning, pulmonary hypertension occurs in a passive way, by the high left atrial pressure that is transmitted backwards as a result of increased resistance against the pulmonary venous drainage. In later periods, pulmonary vasoconstriction and anatomic changes of the vessels would be added to the procedure. This pulmonary status that occurs in patients with mitral valve disease is called as "Mitral Lung" and mostly includes obstructive and/or restrictive pulmonary dysfunction and pulmonary trunk stenosis [1]. As a nonphysiological procedure, cardiopulmonary bypass (CPB) causes hemodilution, increase in body fluids and inflammatory response that causes organ dysfunction [2]. CPB, decreases pulmonary compliance, increases pulmonary resistance, corrupts alveolar gas exchange and pulmonary endothelial 
functions and by the way creates pulmonary dysfunction [3]. This process leads to nitric oxide synthesis which is responsible from the pulmonary vasodilation. Also, hypothermia, contact of the blood with extracorporeal surfaces like tubing lines and hemodynamic changes due to $\mathrm{CPB}$ result in the release of inflammatory mediators. This inflammatory response contributes pulmonary injury that was primarily promoted with antigens in donor blood and/or fresh frozen plasma used during or after open heart surgery [4-6]. Particularly in patients with poor preoperative pulmonary functions, postoperative pulmonary complications due to CPB are seen more often and severely. On the other hand, it was determined that perioperative use of blood products extend mechanical ventilation time, hospital stay, increase the risk of acute lung injury due to transfusion, incidence of infection, acute kidney injury, and mortality after cardiac surgery [7-9]. Processing the blood by cell salvage or ultrafiltration (UF) increases the hematocrit and hemoglobin levels $[5,10]$. Also, UF removes the excess water, cytokines, toxins, concentrate coagulation factors, decreases tissue edema and inflammatory response to CPB [11, 12]. By the time, different UF techniques were developed such as "Conventional UF (CUF)" which is applied during CPB via a haemofilter inserted into the bypass circuit, "Modified UF (MUF)" which is applied after CPB, before protamine administration with blood removed from arterial line and returned to the venous line after passing through the haemofilterand "Zero-balanced UF (Z-BUF)" in which a balanced electrolyte solution is given as much as the volume taken [13]. MUF is used frequently in congenital heart surgery and its benefits are determined clearly in literature [14-16]. However, mixed results and controversy is present about the use of UF techniques in adult patients [17]. The aim of this study is to determine the effects of CUF, especially in patients undergoing mitral valve surgery with severe secondary pulmonary hypertension.

\section{Method}

This study was conducted with local ethics committee approval. 40 patients undergoing mitral valve surgery with high pulmonary artery pressure (PAP $>50 \mathrm{mmHg}$ ) and high pulmonary capillary wedge pressure $(\mathrm{PCWP}>15 \mathrm{mmHg}$ ) were prospectively randomised into two groups. CUF was applied in the study group $(n=20)$ at the end of the CPB and patients in the control group did not receive any type of ultrafiltration. CUF was chosen for this study in order to avoid the hemodynamic imbalance and to intervene more easily if any hemodynamic problem occurs. Patientswhohave mild aortic or tricuspid valve disease accompanying to mitral valve disease without any surgical indication were also included in the study. Age, gender, height, weight, body surface area (BSA), preoperative transthoracic echocardiography, respiratory functions, complete blood count (CBC), and biochemical parameters of the patients were evaluated. A standard anesthesia protocol which was used by anesthesiology department for cardiac surgery (for induction: $0.05-0.1 \mathrm{mg} / \mathrm{kg}$ midazolam, $15 \mathrm{mcg} / \mathrm{kg}$ fentanyl, 2 $\mathrm{mg} / \mathrm{kg}$ propofol, $0.1 \mathrm{mg} / \mathrm{kg}$ pancuroniumbromide, for maintenance: $6-8 \mathrm{mcg} / \mathrm{kg} / \mathrm{h}$ fentanyl, $2 \mathrm{mg} / \mathrm{kg} / \mathrm{h}$ propofol, $0.01 \mathrm{mg} / \mathrm{kg}$ pancuronium bromide (in every $60 \mathrm{~min}$.)) was performed to all patients. After induction, Swan-Ganz Continuous Cardiac Output (CCO) thermodilution flowdirected pulmonary artery catheter, 7.5 F was inserted. Preoperative values of PAP, PCWP, central venous pressure (CVP), mean airway pressure (MAP), peak inspiratory pressure (PIP), tidal volume (V tidal), respiratory rate (RR), positive end-expiratory pressure (PEEP), fraction of inspired oxygen $\left(\mathrm{FiO}_{2}\right)$, cardiac index $(\mathrm{CI})$ and blood gases were noted. Cardiac output monitor (Edwards Lifesciences LLC, Vigilance Monitor, Irvine, CA, USA, 2001) was used for CI measurements. All patients were operated via median sternotomy under moderate $\left(28^{\circ} \mathrm{C}\right)$ hypothermic cardiopulmonary bypass. Antegrade cold blood cardioplegia was used for cardiac arrest and myocardial protection. In study group, CUF was applied with polyethersulfonehemoconcetrator (Sasan Medical Products, Ankara, Turkey, 2008) at the end of CPB. Ultrafiltration rate was adjusted as $20 \mathrm{ml} / \mathrm{kg}$ in total or at least equal to priming volume. At the end of cardiopulmonary bypass, parameters including PAP, PCWP, CVP, MAP, PIP, V tidal, RR, PEEP, $\mathrm{FiO}_{2}, \mathrm{CI}$ and blood gases were re-evaluated. Alterations in these parameters at postoperative $2^{\text {nd }}$ hour were analysed. $\mathrm{CBC}$ and biochemical parameters were analysed at postoperative $2^{\text {nd }}$ and $24^{\text {th }}$ hours. Amount of surgical bleeding, use of inotropic agents and blood products, intubation time, ICU stay, hospital stay, morbidity and mortality were also analyzed. Pre and postoperative pulmonary compliance $(\mathrm{CP})$, oxygen index (OI), alveolararterial oxygen pressure difference $\left(\mathrm{p}(\mathrm{A}-\mathrm{a}) \mathrm{O}_{2}\right)$, respiratory index (RI) and ventilation index (VI) values were analysed.

For statistical analysis, SPSS (Statistical Package for Social Sciences) for Windows 18.0 program was used. Results were evaluated at confidence interval of $95 \%$ and the $\mathrm{p}<0.05$ levels were considered statistically significant.

\section{Result}

Demographic data, preoperative transtohoracic echocardiography and operative values were given in Table1. 
Table 1. Demographic data, preoperative transthoracic echocardiography and operative values.

\begin{tabular}{|c|c|c|c|c|}
\hline & Study Group(mean+SD) & Control Group(mean+SD) & $\mathbf{P}$ & Total(mean+SD) \\
\hline Male & 8 & 12 & \multirow{2}{*}{$>0.05$} & 20 \\
\hline Female & 12 & 8 & & 20 \\
\hline Age (years) & $45.00 \pm 12.11$ & $51.50 \pm 9.82$ & $>0.05$ & $48.25 \pm 11.24$ \\
\hline Preop. PAP (mmHg) & $59.90 \pm 6.58$ & $60.80 \pm 11.39$ & $>0.05$ & $59.90 \pm 9.10$ \\
\hline Preop. PCWP (mmHg) & $21.80 \pm 7.33$ & $20.40 \pm 4.11$ & $>0.05$ & $21.10 \pm 5.83$ \\
\hline Preop. EF \% & $52.40 \pm 7.13$ & $50.10 \pm 11.83$ & $>0.05$ & $51.25 \pm 9.58$ \\
\hline Preop. LVEDD (cm) & $5.28 \pm 0.88$ & $5.11 \pm 0.69$ & $>0.05$ & $5.19 \pm 0.77$ \\
\hline Preop. LAD (cm) & $5.22 \pm 0.88$ & $5.96 \pm 0.56$ & $>0.05$ & $5.59 \pm 0.81$ \\
\hline \multirow{4}{*}{ NYHA } & Class I: 0 & Class I:0 & & Class I: 0 \\
\hline & Class II: 2 & Class II:0 & & Class II: 2 \\
\hline & Class III: 14 & Class III: 14 & & Class III: 28 \\
\hline & Class IV: 4 & Class IV:6 & & Class IV: 10 \\
\hline Bypass Time (min.) & $104.50 \pm 38.49$ & $123.70 \pm 53.33$ & $>0.05$ & $114.10 \pm 46.32$ \\
\hline Cross Clamp Time (min.) & $77.70 \pm 33.87$ & $93.00 \pm 49.52$ & $>0.05$ & $85.35 \pm 42.03$ \\
\hline Body Suface Area $\left(\mathrm{m}^{2}\right)$ & $1.74 \pm 0.17$ & $1.74 \pm 0.14$ & $>0.05$ & $1.74 \pm 0.15$ \\
\hline Priming SolutionVolume (ml.) & $1310.00 \pm 119.72$ & $1230.00 \pm 48.30$ & $>0.05$ & $1270.00 \pm 97.87$ \\
\hline Amount of Ultrafiltrate (ml.) & $1205.00 \pm 265.05$ & - & & - \\
\hline End CPBVolume Balance (ml.) & $595.00 \pm 593.69$ & $770.00 \pm 1259.67$ & $>0.05$ & $682.50 \pm 962.62$ \\
\hline
\end{tabular}

Demographic data, preoperative transthoracic echocardiography and operative values. (abbreviations;CPB: Cardio Pulmonary Bypass, EF: Ejection Fraction, NYHA: New York Heart Association, LAD: Left Arial Diameter, LVEDD: Left Ventricular End Diastolic Diameter, PAP:Pulmonary Artery Pressure, PCWP: Pulmonary Capillary Wedge pressure )

CUF was performed in the study group up to $18-37 \mathrm{~min}$. (mean: $26.30 \pm 6.77 \mathrm{~min}$.) and about 700-1500 ml. (mean: $1205.00 \pm 265.05 \mathrm{ml}$.) ultrafiltrate was taken.

Hematocrit $(28.07 \pm 3.18$ vs. $26.96 \pm 2.51 ; \mathrm{p}>0.05)$ and white blood cell (WBC) increase rate $(13.56 \pm 2.37$ vs. $13.03 \pm 2.51$; $\mathrm{p}>0.05)$ were higher in the study group at postoperative $2^{\text {nd }}$ hour. Postoperative PAP and PCWP levels were significantly lower in both groups $(\mathrm{p}<0.05)$, however, difference of PAP and PCWP decrease rate between the groups were not statistically significant $(\mathrm{p}>0.05)$. The increase rate of CI, OI, increase of $\mathrm{CP}$, decrease of the $\mathrm{p}(\mathrm{A}-\mathrm{a}) \mathrm{O}_{2}$ and $\mathrm{VI}$ were significant in both groups at post-operative $2^{\text {nd }}$ hour $(\mathrm{p}<0.05)$. But, changes of these values between the study and control groups were not statistically significant too $(\mathrm{p}>0.05)$. Postoperative changes in the RI and comparison of these changes between the groups, were also not statistically significant (Table2).

Table 2. Statistical results of the pulmonary parameters.

\begin{tabular}{|c|c|c|c|c|c|c|c|c|c|}
\hline & \multicolumn{2}{|l|}{ Preop. } & \multicolumn{2}{|c|}{ Postop. $2^{\text {nd }}$ Hour } & \multicolumn{2}{|c|}{ Postop.24 ${ }^{\text {th }}$ Hour } & \multicolumn{2}{|l|}{ Postop. $5^{\text {th }}$ Day } & \multirow{2}{*}{$\mathbf{p}$} \\
\hline & Study & control & Study & control & Study & control & Study & control & \\
\hline FEV1/FVC & $103.36 \pm 15.40$ & $100.10 \pm 8.94$ & - & - & - & - & $102.07 \pm 17.42$ & $108.78 \pm 11.63$ & $>0.05$ \\
\hline PAP & $61.50 \pm 9.14$ & $61.60 \pm 13.05$ & & & & & $29.40 \pm 6.62$ & $32.50 \pm 5.89$ & $>0.05$ \\
\hline PCWP & $21.40 \pm 7.78$ & $19.80 \pm 5.27$ & $17.60 \pm 4.17$ & $15.00 \pm 4.35$ & $17.80 \pm 3.52$ & $14.20 \pm 3.64$ & - & - & $>0.05$ \\
\hline C I & $2.27 \pm 0.91$ & $1.99 \pm 0.82$ & $2.94 \pm 0.64$ & $2.50 \pm 0.93$ & $3.19 \pm 1.08$ & $2.55 \pm 0.78$ & - & - & $>0.05$ \\
\hline $\mathrm{CP}$ & $29.76 \pm 5.22$ & $41.72 \pm 6.31$ & $42.28 \pm 6.32$ & $41.41 \pm 6.61$ & - & - & - & - & $>0.05$ \\
\hline OI & $0.0128 \pm 0.005$ & $0.0090 \pm 0.003$ & $0.0298 \pm 0.009$ & $0.0340 \pm 0.028$ & - & - & - & - & $>0.05$ \\
\hline $\mathrm{p}(\mathrm{A}-\mathrm{a}) \mathrm{O}_{2}$ & $242.64 \pm 60.70$ & $263.24 \pm 57.56$ & $123.32 \pm 55.74$ & $131.39 \pm 114.29$ & - & - & - & - & $>0.05$ \\
\hline RI & $0.58 \pm 0.25$ & $0.65 \pm 0.23$ & $0.86 \pm 0.57$ & $1.22 \pm 1.63$ & - & - & - & - & $>0.05$ \\
\hline VI & $7.97 \pm 2.33$ & $5.62 \pm 1.32$ & $5.39 \pm 0.75$ & $5.88 \pm 2.01$ & - & - & - & - & $>0.05$ \\
\hline
\end{tabular}

Statistical results of the pulmonary parameters. (abbreviations;CI: Cardiac Index, CP: Pulmonary Complience, OI: Oxygen Index, FEV1/FVC: Forced expiratory volume during the first second / Forced vital capacity, PAP: Pulmonary Artery Pressure, PCWP: Pulmonary Capillary Wedge Pressure, p(A-a) $\mathrm{O}_{2:}$ alveolar-arterial oxygen pressure difference, RI: Respiratory Index, VI: Ventilation Index)

Total amount of ICU stay ( $42.20 \pm 65.99$ vs. $44.25 \pm 14.13$; $\mathrm{p}<0.05)$, bleeding $(370.00 \pm 216.28$ vs. $506.25 \pm 247.03$; $\mathrm{p}<0.05)$, duration of mechanical ventilation $(7.97 \pm 2.77$ vs. $10.12 \pm 2.95 ; \mathrm{p}<0.05)$ and hospitalization period $(7.20 \pm 1.13$ vs. $10.12 \pm 3.27 ; \mathrm{p}<0.05)$ in the study group were significantly shorter than the control group $(\mathrm{p}<0.05)$. No statistically significant difference was present between two groups about the amount of transfusion of blood products $(4.20 \pm 1.23$ vs. $4.90 \pm 2.13 ; \mathrm{p}>0.05$ ) and use of inotropic agents (no inotrop:6, inotrop used:14 vs. no inotrop:2, inotrop used:18; $p>0.05$ ). However, use of blood products and use of two or more inotropic agents in study group (\%10) were less than the control group $(\% 50)$ (Table 3). 
Table 3. Statistical results of ICU Stay, intubation time, amount of surgical bleeding, transfusion of blood products, hospital stay, use of inotropic agents and morbidity.

\begin{tabular}{llll}
\hline & Study Group(mean \pm SD) & Control Group(mean \pm SD) & p \\
\hline ICU stay (hours) & $42.20 \pm 65.99$ & $44.25 \pm 14.13$ & $<0.05$ \\
Intubation period (hours) & $7.97 \pm 2.77$ & $10.12 \pm 2.95$ & $<0.05$ \\
Surgical bleeding (ml.) & $370.00 \pm 216.28$ & $506.25 \pm 247.03$ & $<0.05$ \\
Transfusion of bloodproducts (units) & $4.20 \pm 1.23$ & $4.90 \pm 2.13$ & $>0.05$ \\
Hospitalization (days) & $7.20 \pm 1.13$ & $11.60 \pm 4.25$ & $<0.05$ \\
Use of inotropic agents & & & \\
no inotropic agent & $\mathrm{n}: 6(\% 30.0)$ & $\mathrm{n}: 2(\% 10.0)$ & $>0.05$ \\
one inotropic agent & $\mathrm{n}: 12(\% 60.0)$ & $\mathrm{n}: 8(\% 40.0)$ & \\
2 or more inotropic agents & $\mathrm{n}: 2(\% 10.0)$ & $\mathrm{n}: 10(\% 50.0)$ & \\
Morbidity & 0 & 0 & \\
\hline
\end{tabular}

Statistical results of ICU Stay, intubation time, amount of surgical bleeding, transfusion of blood products, hospital stay, use of inotropic agents and morbidity.(abbreviations; ICU: Intensive Care Unit, ml: milliliter)

Also, no morbidity and no mortality was present due to CUF in both groups.

\section{Discussion}

Despite all the technological and methodological developments in cardiac surgery, use of CPB still has negative effects on organs such as increased myocardial edema, coronary vasoconstriction, perivascular and interstitial pulmonary edema, increased tendency for atelectasis, intraalveolar congestion, decreased renal perfusion, acute tubulary necrosis, confusion, agitation, delirium, prolonged sleepiness, transient parkinsonism, decreased insulin response, metabolic asidosis, intestinal malabsorbsionetc [18]. In case of mitral valve disease, patients with secondary pulmonary hypertension due to valvular disease, negative effects of $\mathrm{CPB}$ and additional factors such as general anesthesia, sternotomy, mechanical ventilation-induced acute lung injury, hypothermia, surgical trauma, medications and/or transfusion of blood products may contribute in pulmonary dysfunction [19, 20]. Use of ultrafiltration was thought to be an effective choice for improving the $\mathrm{CP}$ and gas exchange, which may successfully reduce the pulmonary dysfunction [12, 21-23].

However, there are debates about ultrafiltration methods and used filters [3, 24]. MUF and/or CUF can be used in adult cardiac surgery for removing the excess water, in case of enough volume in the reservoir. Due to the small volume in the venous reservoir and usage of limited prime solution MUF is prefered particularly in pediatric cardiac surgery. As results of their studies; Zhou et al. determined significant improvement in myocardial function [25], Ricci et al [26], Yokoyama et al [27], Hodges et al [28] and Naik et al [29] determined significant increase in blood pressure, Chaturvedi et al determined significant improvement in global left ventricle function after MUF [30]. Also, Keenan et al [31] determined imrovement in dynamic and static CP, Liu et al determined decrease in entubation period and ICU stay [32], Onoe et al [33] and Mahmoud et al [2] determined improved pulmonary functions. In adults, any type of ultrafiltration may preserve hemostasis and decrease the use of blood products [22]. It is still controversial whether to use MUF,
CUF or both together to achieve best pulmonary functions. Torina et al reported that MUF decreased amount of surgical bleeding and use of blood products postoperatively, but did not make any difference in pulmonary parameters. Also, MUF was not effective for improving the inflammatory response and decreasing the ICU or hospitalization periods [11]. In their study, Kosouret al stated that no statistically significant difference was present in pulmonary parameters between the control and ultrafiltration applied groups [12]. In this study, improvements in PAP, PCWP, CP, OI, p(A-a) $\mathrm{O}_{2}$, RI and VI parameters due to the correction of valvular pathology in both groups were determined. However, in the comparison of groups, no statistically significant difference was present due to CUF at postoperative $2^{\text {nd }}$ hour between the study and control groups.

On the other hand, ultrafiltration has significant effects on other surgical and postoperative follow up parameters such as amount of surgical bleeding, transfusion of blood products, length of entubation period, ICU stay, use of inotropic agents and hospitalization. Cardiac surgery remains one of the greatest consumers of blood products. Despite the studies those report the benefit of ultrafiltration, it is used less frequently in adult cardiac surgery [34]. Boodhwani et al reported significant decrease in surgical blood loss by using ultrafiltration in the metaanalysis of 11 articles. CUF alone was used in 5, MUF alone or together with CUF was used in 6 of them [5]. Kiziltepe et al and Sever et al determined that hematocrit and WBC levels were higher in study groups. They also determined that surgical blood loss and transfusion of blood products were lesser than the control groups [4, 35]. Luciani GB et al reported that intubation time, ICU and hospitalization periods were shorter, mortality and morbidity were less in their study group. They demonstrated that the MUF has no complication and was cost-effective [36]. Kiziltepe et al also reported that use of inotropic agents were higher in the control group. Nevertheless, that was not statistically significant [4]. In this study, CUFwas applied alone and obtained significant better results about intubation periods $(7.97 \pm 2.77$ vs. $10.12 \pm 2.95 ; \mathrm{p}<0.05)$, ICU stay (42.20 \pm 65.99 vs. $44.25 \pm 14.13 ; \mathrm{p}<0.05)$ amount of bleeding $(370.00 \pm 216.28 \quad$ vs. $506.25 \pm 247.03 ; \quad \mathrm{p}<0.05) \quad$ and hospitalization periods (7.20 \pm 1.13 vs. $10.12 \pm 3.27$; $<<0.05)$. 
Although statistically insignificant, also some increase in hematocrit and WBC, decrease in need for transfusion of blood products and decrease in use of inotropic agents were determined.

\section{Conclusion}

Usage or type of ultrafiltration in adult cardiac surgery is still controversial. As the result of this study, particularly in patients with poor pulmonary functions, use of CUF is recommended. Beside the improving effects of CUF over hematocrit levels, surgical blood loss, need for transfusion of blood products and use of inotropic agents, by using CUF, the extravascular volume load can be removed without the risk of hemodynamic imbalance which is mostly seen in MUF. By the way, the increased risks for perivascular and interstitial pulmonary edema, increased tendency for atelectasis, and intraalveolar congestion which are caused due to valvular disease and use of cardiopulmonary bypass, can be reduced. The insignificant results of this study might be caused due to the small cohort of patients included in the study. Designing a new study with a larger patient population would yield more statistically significant results. Application of CUF and MUF together instead of CUF alone might help us to obtain statistically significant results in pulmonary parameters.

\section{Disclosures}

The authors declared no conflicts of interest for this manuscript.

The authors received no financial support for this manuscript.

This manuscript has not been published previously elsewhere.

\section{References}

[1] Schlant RC, Alexander RW. Techniques of evaluating pulmonary function in patients with cardiac disease in Hurst's The Heart, 8th ed., New York, McGraw-Hill, 1994. 441-445p.

[2] Mahmoud AB, Burhani MS, Hannef AA, Jamjoom AA, AlGithmi IS, Baslaim GM. Effect of modified ultrafiltration on pulmonary function after cardiopulmonary bypass. Chest. 2005; 128:3447-3453.

[3] Huang H, Yao T, Wang W, Zhu D, Zhang W, Chen H, Fu W. Continuous ultrafiltration attenuates the pulmonary injury that follows open heart surgery with cardiopulmonary bypass. Ann Thorac Surg. 2003; 76:136-140.

[4] Kiziltepe U, Uysalel A, Corapcioglu T, Dalva K, Akan H, Akalin H. Effects of combined conventional and modified ultrafiltration in adult patients. Ann Thorac Surg. 2001; 71:684-693.

[5] Boodhwani M, Williams K, Babaev A, Gill G, Saleem N, Rubens FD. Ultrafiltration reduces blood transfusions following cardiac surgery: A meta-analysis. Eur J Cardiothorac Surg. 2006; 30:892-897.

[6] Hall R. Identification of inflammatory mediators and their modulation by strategies for the management of the systemic inflammatory response during cardiac surgery. J Cardiothoracic Vasc Anesth. 2013; 27:983-1033.

[7] Redlin M, Kukucka M, Boettcher W, Schoenfeld H, Huebler M, Kuppe H, Habazettl H. Blood transfusion determines postoperative morbidity in pediatric cardiac surgery applying a comprehensive blood-sparing approach. J ThoracCardiovasc Surg. 2013; 146:537-542.

[8] Salvin JW, Scheurer MA, Laussen PC, Wypij D, Polito A, Bacha EA, Pigula FA, McGowan FX, Costello JM, Thiagarajan RR. Blood transfusion after pediatric cardiac surgery is associated with prolonged hospital stay. Ann Thorac Surg. 2011; 91:204-210.

[9] Wolf MJ, Maher KO, Kanter KR, Kogon BE, Guzzeta NA, Mahle WT. Early postoperative bleeding is independently associated with increased surgical mortality in infants after cardiopulmonary bypass. J ThoracCardiovasc Surg. 2014; 148:631-636.

[10] Society of Thoracic Surgeons Blood Conservation Guideline Task Force, Ferraris VA, Brown JR, Despotis GJ, Hammon JW, Reece TB, Saha SP, Song HK, Clough ER; Society of Cardiovascular Anesthesiologists Special Task Force on Blood Transfusion, Shore-Lesserson LJ, Goodnough LT, Mazer CD, Shander A, Stafford-Smith M, Waters J; International Consortium for Evidence Based Perfusion, Baker RA, Dickinson TA, FitzGerald DJ, Likosky DS, Shann KG. 2011 update to the Society of Thoracic Surgeons and the Society of Cardiovascular Anesthesiologists blood conservation clinical practice guidelines. Ann Thorac Surg. 2011; 91:944-982.

[11] Torina AG, Silveira-Filho LM, Vilarinho KA, Eghtesady P, Oliveira PP, Sposito AC, Petrucci O. Use of modified ultrafiltration in adults undergoing coronary artery bypass grafting is associated with inflammatory modulation and less postoperative blood loss: a randomized and controlled study. J ThoracCardiovasc Surg. 2012; 144:663-670.

[12] Kosour C, Dragosavac D, Antunes N, Almeida de Oliveira RA, Martins Oliveira PP, Wilson Vieira R. Effect of ultrafiltration on pulmonary function and interleukins in patients undergoing cardiopulmonary bypass. CardiothoracVascAnesth. 2016; 30:884-890.

[13] Sarkar M, Prabhu V. Basics of cardiopulmonary bypass. Indian J Anaesth. 2017; 61:760-767.

[14] Atkins BZ, Danielson DS, Fitzpatrick CM, Dixon P, Petersen RP, Carpenter AJ. Modified ultrafiltration attenuates pulmonary-derived inflammatory mediators in response to cardiopulmonary bypass. Interact CardiovascThorac Surg. 2010; 11:599-603.

[15] Raja SG, Dreyfus GD. Modulation of systemic inflammatory response after cardiac surgery. Asian CardiovascThorac Ann. 2005; 13:382-395.

[16] Chew MS, Brix-Christensen V, Ravn HB, Brandslund I, Ditlevsen E, Pedersen J, Hjortholm K, Hansen OK, Tønnesen E, Hjortdal VE. Effect of modified ultrafiltration on the inflammatory response in paediatric open-heart surgery: a prospective, randomized study. Perfusion. 2002;17: 327-333.

[17] Grunenfelder J, Zund G, Schoeberlein A, Maly FE, Schurr U, Guntli S, Fischer K, Turina M. Modified ultrafiltration lowers adhesion molecule and cytokine levels after cardiopulmonary bypass without clinical relevance in adults. Eur J Cardiothorac Surg. 2000; 17:77-83. 
[18] Hannan EL, Wu C, Smith CR, Higgins RS, Carlson RE, Culliford AT, Gold JP, Jones RH. Off-pump versus on-pump coronary artery bypass graft surgery: differences in short-term outcomes and in long-term mortality and need for subsequent revascularization. Circulation. 2007; 116:1145-1152.

[19] Wynne R, Botti M: Postoperative pulmonary dysfunction in adults after cardiac surgery with cardiopulmonary bypass: Clinical significance and implications for practice. Am J Crit Care 2004; 13:384-393.

[20] Cepkova M, KapurV, RenX, Quinn T, Zhuo H, Foster E, Liu $\mathrm{KD}$, Matthay MA. Pulmonary dead space fraction and pulmonary artery systolic pressureas early predictors of clinical outcome in acute lung injury. Chest 2007; 132:836842 .

[21] Koike T, Tsuchida M, Saitoh M, Haga M, Satoh K, Aoki T, Toyabe SI, Hayashi JI. Protective mechanism of ultrafiltration against cardiopulmonary bypass-induced lung injury. Transplant Proc. 2009; 41:3845-3848.

[22] Pérez-Vela JL, Ruiz-Alonso E, Guillén-Ramírez F, GarcíaMaellas MT, Renes-Carreño E, Cerro-García M, CortinaRomero J, Hernández-Rodríguez I. ICU outcomes in adult cardiac surgery patients in relation to ultrafiltration type. Perfusion. 2008; 23:79-87.

[23] Apostolakis EE, Koletsis EN, Baikoussis NG, Siminelakis SN, Papadopoulos GS. Strategies to prevent intraoperative lung injury during cardiopulmonary bypass. JCardiothorac Surg. 2010; 5:1.

[24] Berdat PA, Eichenberger E, Ebell J, Pfammatter JP, Pavlovic M, Zobrist C, Gygax E, Nydegger U, Carrel T. Elimination of proinflammatory cytokines in pediatric cardiac surgery: Analysis of ultrafiltration method and filter type. J ThoracCardiovasc Surg 2004; 127:1688-1696.

[25] Zhou G, Feng Z, Xiong H, Duan W, Jin Z. A combined ultrafiltration strategy during pediatric cardiac surgery: a prospective, randomized, controlled study with clinical outcomes. J CardiothoracVascAnesth. 2013; 27:897-902.

[26] Ricci Z, Polito A, Netto R, De Razza F, Favia I, Carotti A, Cogo PE. Assessment of modified ultrafiltration hemodynamic impact by pressure recording analytical method during pediatric cardiac surgery. PediatrCrit Care Med. 2013; 14:390-395

[27] Yokoyama K, Takabayashi S, Komada T, Onoda K, Mitani Y,
Iwata H, Shimpo H. Removal of prostaglandin E2 and increased intraoperative blood pressure during modified ultrafiltration in pediatric cardiac surgery. J ThoracCardiovascSurg. 2009; 137:730-735.

[28] Hodges UM, Berg S, Naik SK, Bower S, Lloyd-Thomas A, Elliot M. Filtration of fentanyl is not the cause of the elevation of arterial blood pressure associated with post-bypass ultrafiltration in children. J CardiothoracVascAnesth. 1994; 8:653-657.

[29] Naik SK, Balaji S, Elliott MJ. Modified ultrafiltration improves hemodynamics after cardiopulmonary bypass in children. J Am CollCardiol. 1992; 19:37A.

[30] Chaturvedi RR, Shore DF, White PA, Scallan MH, Gothard JW, Redington AN, Lincoln C. Modified ultrafiltration improves global left ventricular systolic function after openheart surgery in infants and children. Eur J Cardiothorac Surg. 1999; 15:742-746.

[31] Keenan HT, Thiagarajan R, Stephens KE, Williams G, Ramamoorthy C, Lupinetti FM. Pulmonary function after modified venovenous ultrafiltration in infants: a prospective, randomized trial. J ThoracCardiovasc Surg. 2000; 119:501505 .

[32] Liu JP, Long C, Feng ZY, Ji BY, Li CH. Comparative study of pulmonary function after conventional ultrafiltration or modified ultrafiltration during cardiac surgery of infants. Zhongguo Yi XueKeXue Yuan XueBao. 2002; 24:364-366.

[33] Onoe M, Oku H, Kitayama H, Matsumoto T, Kaneda T. Modified ultrafiltration may improve postoperative pulmonary function in children with a ventricular septal defect. Surg Today. 2001; 31:586-590.

[34] MongeroL, Stammers A, Tesdahl E, Stasko A, Weinstein S. The effect of ultrafiltration on end-cardiopulmonary bypass hematocrit during cardiac surgery. Perfusion. 2018; $1: 267659117747046$.

[35] Sever K, Tansel T, Basaran M, Kafali E, Ugurlucan M, Ali Sayın O, Alpagut U, Dayıglu E, Onursal E. The benefits of continuous ultrafiltration in pediatric cardiac surgery. ScandCardiovasc J 2004;38: 307-311.

[36] Luciani GB, Menon T, Vecchi B, Auriemma S, Mazzucco A. Modified ultrafiltration reduces morbidity after adult cardiac operations: a prospective, randomized clinical trial. Circulation. 2001; 104:I253-259. 